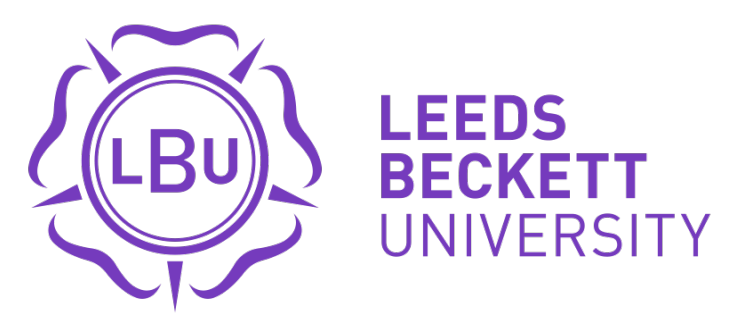

Citation:

Herron, T (2019) A vision of Ireland, 1967: John Montague's aisling ghéar. Irish Studies Review, 27 (2). pp. 161-176. ISSN 0967-0882 DOI: https://doi.org/10.1080/09670882.2019.1600643

Link to Leeds Beckett Repository record:

https://eprints.leedsbeckett.ac.uk/id/eprint/6893/

Document Version:

Article (Accepted Version)

This is an Accepted Manuscript of an article published by Taylor \& Francis in Irish Studies Review on 15 April 2019, available online: http://www.tandfonline.com/10.1080/09670882.2019.1600643

The aim of the Leeds Beckett Repository is to provide open access to our research, as required by funder policies and permitted by publishers and copyright law.

The Leeds Beckett repository holds a wide range of publications, each of which has been checked for copyright and the relevant embargo period has been applied by the Research Services team.

We operate on a standard take-down policy. If you are the author or publisher of an output and you would like it removed from the repository, please contact us and we will investigate on a case-by-case basis.

Each thesis in the repository has been cleared where necessary by the author for third party copyright. If you would like a thesis to be removed from the repository or believe there is an issue with copyright, please contact us on openaccess@leedsbeckett.ac.uk and we will investigate on a case-by-case basis. 


\title{
A vision of Ireland, 1967: John Montague's aisling ghéar
}

\section{Tom Herron}

School of Cultural Studies and Humanities, Leeds Beckett University, Leeds, UK

t.herron@leedsbeckett.ac.uk

\section{Author biography}

Tom Herron is a lecturer in English and Irish literature at Leeds Beckett University. He is co-author of After Bloody Sunday: Representation, Ethics, Justice (Cork University Press, 2007) and is editor of Louis MacNeice's I Crossed the Minch (Polygon, 2008); The Harrowing of the Heart: The Poetry of Bloody Sunday (Guildhall, 2008); and Irish Writing London (Bloomsbury, 2013). He is currently working on a monograph entitled The Real Things: Seamus Heaney's Poetry of Objects (Manchester University Press, 2020).

\begin{abstract}
More than fifty years after its publication as a broadsheet ballad, John Montague's "The Rape of the Aisling" (1967) retains its satirical force. Whilst not the first instance in Irish writing to acknowledge sexual abuse of young people by priests (two years earlier John McGahern's The Dark had been banned partly on the grounds of its rendering of clerical malfeasance), Montague's rough ballad nonetheless places sexual abuse at the very heart of its assault on the Catholic Church's baleful influence on an society on the cusp of dramatic social change. By adopting, and radically adapting, that most malleable of literary forms - the aisling or dream-vision poem - Montague seems to suggest that in mid-twentieth-century Ireland it is not the "Saxon occupier" who poses a risk to Republican ideals. Now, it is members of a home-grown patriarchy, the "access-all-areas men in black" who abuse and rape children and young people in their care, who seek to compromise the Proclamation's promise to cherish "all of the children of the nation equally".
\end{abstract}

Keywords

John Montague; aisling; Catholic Church; clerical sexual abuse; ballad, satire. 


\section{A vision of Ireland, 1967: John Montague's aisling ghéar}

Anti-clericalism of the negative, secular type has of yet put down no roots in Ireland. It has to contend with a massive weight of historical tradition. For the old and middleaged, no matter what the degree of sophistication or religious commitment, respect for the cloth is inbred and virtually automatic (every Irishman, it used to be said, is a prêtre manqué!). Even the questioning young have shown no real change in this regard.

John A. Murray ${ }^{1}$

\section{THE RAPE OF THE}

$\begin{array}{llllllll}A & I & S & L & I & N & G\end{array}$

\section{A NEW SONG}

Upon a hillside fair she stood

Wondrous neat in her Kinsale hood

So I softly undid her little snood

O my culchie darling!

And then my hands wound round her neck

As gently I eased her upon her back

In the tufty smell of a new haystack

O my culchie darling!

Through her hair's long lustrous ripple

Gleamed the rose petal of her nipple:

'Twould arouse a sleeping cripple,

O my culchie darling!

She swore she was true Gael and free

So I placed my hand above her knee,

And all the rest of her country -

O my culchie darling! 
The glories exposed to my downcast eyes,

The buttermilk sheen upon her thighs,

Made all my pride and glory rise

O my culchie darling!

The rutted track we galloped then

Is the best of all that's open to men

But leads you far from the priest's amen:

O my culchie darling!

My guardian angel in the weeping dawn

Showed that her I held my paragon

Was only the usual parcel of bone

O my culchie darling!

So soon as I got back my senses

I hurried home to the smell of incense

And wore my knees in long repentance

O my culchie darling!

DUBLIN

5th of June 1967

ST SEPULCHRE'S PRESS ${ }^{2}$

A few days after John McGahern's death in March 2006, Fintan O’Toole set out what he saw as the novelist's defining achievement:

by accurately describing the human interiors of Ireland, McGahern helped to alter Ireland's sense of reality. The starkest example of this is the issue of child sex abuse. When it hit the headlines in the 1990s, it was spoken of as a stunning and awful revelation, a secret that hardly anyone knew. Yet it is there in black and white in The Dark, thirty years before. ${ }^{3}$ 
More pointedly, Frank Shovlin alerts us to the fact that McGahern's 1965 novel depicts the abusive behavior of a Catholic priest, making it "perhaps the first major work of fiction in Ireland to shine a light on clerical sexual abuse. ${ }^{4}$ But while the sexual violence meted out to Mahoney by his father is explicitly and quite horribly drawn, the instance of clerical abuse is considerably less graphic. All the same, it was the scene in which a priest enters the boy's bed that, as McGahern ruefully put it, "may have caused the subsequent trouble." Not only was the novel banned on the grounds of obscenity by the Censorship of Publications Board, but its author was dismissed from his teaching post at St. John the Baptist Junior Boys School in Clontarf on the instructions of the Archbishop of Dublin, John Charles McQuaid. ${ }^{6}$

That the "McGahern case" was for a time the subject of newspaper, radio, and television reporting as well as questions in Dáil Éireann ${ }^{7}$ reminds us that although the Catholic Church continued to hold sway in mid-nineteen sixties Ireland, it was by no means immune to criticism. Indeed, that generation of writers associated with the “Counter Revival” - Frank O'Connor and Seán O'Faoláin foremost among them - had articulated a broad dissatisfaction with the Church's influence on the State well before the sixties. Perhaps the most notable example of dissent came in 1951 with the widespread public anger in response to the Church's role in sabotaging, with the assistance of the Irish Medical Association, Noël Browne's Mother and Child Scheme, an anger compounded by John A. Costello's Government's pusillanimity towards the Church and other vested interests. O'Faoláin's bravura contribution to the debate demonstrates that, in some quarters at least, biting criticism could be levelled at the unhealthy intersection of Church and State:

Here in the Republic, as this crisis has revealed to us, we have two parliaments: a parliament at Maynooth and a parliament in Dublin. I do not know whether a country can be ruled satisfactorily by two parliaments. Ours has - as the crisis has suddenly revealed - been so ruled since it was founded. ... The so-called Republican tradition and all the bye-echoes of that tradition - in so far as they ever really clarified themselves - are washed up. ${ }^{8}$

Contrary to John A. Murray's assertion - made in 1969 - that anti-clericalism had no foothold in Ireland, the examples of O'Faoláin and O'Connor, not to mention 
the presence of magazines such as The Dublin Journal, The Bell, and Dublin Opinion, and, from July 1962, the powerful influence on national debate of RTÉ's The Late Late Show, provide plenty of evidence that criticism of the Church was far from unknown in early- to mid-1960s Ireland. Indeed, just a couple of years before the publication of The Dark, Austin Clarke had excoriated the Church hierarchy in his Flight to Africa (1963), an "astonishingly lecherous, anti-clerical work", 9 as John Montague gleefully greeted the latest installment of Clarke's satirical attacks on Church and State. The truth of the matter, however, is that despite occasional criticism of aspects of its influence and governance, the Catholic Church in mid-nineteen sixties Ireland maintained the privileged position it had established for itself at the foundation of the modern State, a position guaranteed by Bunreacht na hÉireann, Section 44.1.2 of which reads "The State recognises the special position of the Holy Catholic Apostolic and Roman Church as the guardian of the Faith professed by the great majority of the citizens." As Angela Bourke says of the priests who seem omnipresent in Peter Lennon's documentary The Rocky Road to Dublin (1967): "no shadow has fallen across them yet; they behave as though they owned the place, and so does everybody else."10

By rendering the sexual grooming of a child by a priest and by offering no obvious repercussions for Father Gerald (who is, just to complicate matters, Mahoney's cousin), McGahern's novel hints towards the maleficence of some members of the Catholic clergy decades prior to the uncovering of mistreatment by priests, nuns, and Christian Brothers in schools, churches, laundries, parochial houses, orphanages, hospitals, and a host of other locations in which officials of the church had access to children and young people. ${ }^{11}$ It hints also at a tremendous confidence that their actions would have no consequences: a situation that, in the world beyond the novel, would indeed be the case for decades to come. The bedroom scene is, as O'Toole puts it, "eerily like something that would be spoken aloud in Ireland decades later in States of Fear or the Ferns Inquiry ... and though most Irish people knew ... they did not want to really know", ${ }^{12}$ an observation borne out by the almost total lack of any reference to clerical abuse in the furore that followed the ban. ${ }^{13}$ Bourke experiences a similar unease as she watches The Rocky Road to Dublin in the wake of the Ferns Inquiry:

the children we see in [the film] may have been safe, but hundreds just like them were being raped and tortured by some of the most revered members of society; the access- 
all-areas men in black who systematically terrified them into keeping sick secrets. These men were a minority but their poison still lives on. Senior clerics, smiling or solemn, knew all about it too, for there were complaints. The first recorded and acted upon in Ferns was in 1966; a priest was removed from his teaching post and sent to England for two years as penance. He was later appointed principal of the same school and continued to abuse the boys in his care. ${ }^{14}$

Marie Keenan, also reflecting on Ferns, argues that there is now "sufficient literature available ... to suggest that despite their protestations to the contrary, the Catholic Church hierarchy in Ireland ... had knowledge of sexual abuse by clergy from the 1960s onwards." 15 Diarmaid Ferriter is less equivocal and goes even further back: "there is now no doubt that from the 1930s the Church authorities were aware of sexual abuse and had canon law structures in place to deal with it."16

In the "culture of containment" that shaped Irish civil and religious life until at least the nineteen sixties, ${ }^{17}$ it was probably to be expected that The Dark and Rocky Road were, in their different ways, silenced. ${ }^{18}$ This makes it all the more surprising that a vastly more searing attack on the unchecked power of the Church produced at almost exactly the same time passed unnoticed beneath the censor's gaze. Unlike McGahern's sober exploration of "the conflict between the call to the priesthood and sexual desire", ${ }^{19}$ and unlike Lennon's "mordant" but "witty" ${ }^{20}$ portrait of an Ireland on the cusp of economic and cultural change, the deleterious effects of clerical power in John Montague's “The Rape of the Aisling” (1967) are satirised ferociously in a form of allegory normally reserved for laments on the collapse of the Gaelic order after Kinsale and the Boyne. Not only is "The Rape of the Aisling" an assault on Church and State relations but it situates those relations in an allegorically-saturated encounter between priest and child. And surprise gives ways to shock when we realise that the encounter is rendered in unequivocally pornographic terms. One might be forgiven for suspecting that the censors were having an off-day when they failed to spot and suppress Montague's poem. But oddly enough, the provisions of the Censorship of Publications Acts and their Amendments (1929 to 1967) stipulated that only books and specific issues of periodicals deemed unsuitable for public consumption were liable to censorship: there was no scope for banning individual poems that appeared in, say, 
newspapers or magazines. ${ }^{21}$ And there was certainly no provision under the Acts to prosecute or suppress the production of individual poems produced by little presses.

"The Rape of the Aisling" was published in broadside format by Mary "Paul" Pollard's St Sepulchre's Press in June $1967 .{ }^{22}$ By adopting the form of the broadside ballad, this "new song" 23 joins a tradition of topical often satirical poetry and song that became popular in eighteenth-century Ireland and continued well into the midnineteenth century. Hand-printed on textured paper, it would immediately have been something of a collector's item, especially as only two-hundred copies were made. In truth, there is a considerable difference between it and those earlier usually anonymous ballads produced cheaply in their thousands, and either pasted onto walls or lamp-posts or sold by street pedlars and singers. It is more than likely that most broadsides are lost to us, having survived little longer than the event that was the object of their ire or lament. But the ephemeral nature of street ballads - especially those that evoke Erin as tutelary goddess - does not diminish the fact that they are reiterations in popular form of a tradition of protest inaugurated by poets, most of them from Munster, associated with eighteenth-century political-allegorical aisling poetry.

A scion of early love-vision poetry (such as the eighth-century 'Aislinge Óenguso') and prophesy poetry (found in parts of the ninth-century Táin Bó Cúailnge), and bearing striking similarities to French traditions of amour courtois, of reverdie or pastourelle poetry imported into Ireland by poets attendant on Hiberno-Norman barons, the political-allegorical aisling is associated primarily with the Irish strain of Jacobitism. Aisling poems typically stage a dream encounter between an impoverished and often dejected poet and a beautiful and other-worldly spéirbhean, or skywoman. Although there is more variation in the form than is generally acknowledged by critics, there are at the same time some immutabilities: the female figure embodies the enfeebled state of Gaelic Ireland in the aftermath of Kinsale, Boyne and Aughrim; there is a compulsive attention to particular features of her body; she prophesises the return of native king or Stuart redeemer, to whom she is betrothed. Sometimes she has suffered sexual violence at the hands of the invaders. At other times she attempts to 
lure the dejected poet away to a life of carefree existence in the West. And occasionally her prophecy is countered by the poet's knowledge that her longed-for redeemer is dead.

"The Rape of the Aisling" is at once part of this tradition of aisling poetry and song, and an act of violence against the tradition. And in revisiting the aisling - as he does throughout his writing career - Montague is by no means alone among recent and contemporary poets. A striking feature of modern Irish poetry is the extent to which the visionary impulse persists. While it is probably fair to say that most contemporary versions are motivated by a desire to demythologise the amalgam of national and sexual politics that the genre relies upon (many contemporary aislingi are therefore "anti-aislingi" housed in a form that mimics the earlier versions), there is another view of the form that is congruent with the satirical thrust of Montague's poem. Seamus Deane holds that the aisling is "less an expression of an unrealistic hope than ... an expression of a permanently rebellious attitude towards the existing order."24 Deane's description accounts for the deployment of the aisling poem at moments of crisis in which a vision of alternative politics and ethics is urgently demanded. Such a moment would arise, for example, in April 1972 when, days after the publication of Lord Chief Justice Widgery's whitewash of the murderous assault on unarmed civilians in Derry on 30 January of that year, Thomas Kinsella hurriedly produced "Butcher's Dozen", his own nightmarish aisling rendered in ballad form and self-published as a chap-book that sold for "Ten New Pence":

The pressures were special, the insult strongly felt, and the timing vital if the response was to matter, in all its kinetic impurity. Reaching for the nearest aid, I found the aisling form - that never quite extinct Irish political verse-form - in a late parodied guise: in the coarse energies and nightmare Tribunal of Merriman's Midnight Court. One changed one's standards, chose the doggerel route, and charged. ${ }^{25}$

As with Kinsella's pamphlet-poem, "The Rape of the Aisling" seems to adopt, not so much the ornate protocols of the baroque high aislingi of Agán Ó Rathaille (notably "Gile na Gile" and "Mac An Cheannaí") or Eoghan Ruadh Ó Súilleabháin ("Ceo Draíochta" in particular), but more the "coarse energies" associated with those street 
ballads in which, George-Denis Zimmerman argues, the aisling had transformed itself "from sophisticated literature into oral tradition or popular song." 26 The coarsening of the aisling from its rhetorically and metrically elaborate early iterations into something more formulaic is read by most commentators as a result of the dawning realization among poets and their audiences that the Williamite dispensation would not be overthrown by the return of native leaders or Stuart monarchs. But Zimmermann argues that even though by the end of the eighteenth century the aisling had "tended to die away as a literary form ... this type of poem wedded to simple tunes made a great impression on the popular mind" and that while "those who are familiar with the intricacies and the beauty of the best Irish texts would be horrified by the poorness of the broadside visions ... the general structure of the genre, and some formal details remained unchanged." ${ }^{27}$ It is this later "impure" incarnation of the aisling with which Montague's poem is most fully in commerce.

It is perhaps no surprise that it is in the work of poets sceptical of the politicalallegorical aisling's "potent blurring of feminine and national" 28 that a reformulated and heavily ironised version of the genre has developed in recent years. Women poets, in particular, have been drawn to the spéirbhean or to the cailleach (old woman) and "have either re-inscribed these iconic figures with new meanings or, alternatively, reevaluated the silence and passivity that characterises their conventional portrayal." 29 Notable instances of such re-inscriptions or re-evaluations are to be found in "Caitlín"/ "Cathleen" and "The Hag Show” by Nuala Nì Dhomhnaill; "The Colony Room”, "The Aisling Hat", and "The Soil-Map" by Medbh McGuckian; "Remapping the Borders" by Rita Ann Higgins; and "The Singers", "The Women", and "Mise Eire” (perhaps the best-known contemporary "counter-aisling") by Eavan Boland. Each of these poems in different ways and to varying degrees - imagines the woman as an individuated, complex being and not merely as an allegory for the collapse of the Irish aristocratic order and its longed-for restoration. Similarly, poets such as Justin Quinn ("UrAisling") and Peter McDonald (“A Volume of Memoirs is Forthcoming”) have revisited the genre with a mixture of embarrassment at, and disdain for, its mythological underpinning, and have pointed to the exorbitant demands placed upon the male interlocutor by the spéirbhean or the cailleach. Paul Muldoon has frequently invoked the aisling: in "Sky-Woman" for purposes far removed from any concern with 
the state of the nation, and in "The More a Man Has the More a Man Wants" and "Aisling" for purposes very close indeed to the fate of the northern statelet:

Was she Aurora, or the goddess Flora,

Artemidora, or Venus bright,

or Anorexia, who left

a lemon stain on my flannel sheet?

It's all much of a muchness.

In Belfast's Royal Victoria Hospital

a kidney machine

supports the latest hunger-striker

to have called off his fast, a saline

drip into his bag of brine. ${ }^{30}$

Muldoon's version of aisling exemplifies the distance travelled from the formal procedures of the classical aisling or the street ballad, a distance magnified by the poem's simultaneous disavowal of the genre ('It's all much of a muchness' seeming to dismantle from the inside Ó Rathaille's "Gile na Gile”) and its sense of the power of myth to shape human actions and destiny: now Anorexia takes her place among the pantheon of goddess muses. Michael O'Loughlin's “Medium”, too, restages the aisling encounter but now the prophecy of the spéirbhean undergoes the fraught process of translation as it is channelled via a psychic medium whose job it is to decipher fragments of information arising from the spirit world. In fact, it may well be the “founding father" of the political-allegorical aisling, Agán Ó Rathaille, whose words "Gile na Gile", come to the medium in broken form. So broken in fact, that whatever vision there may once have been now fails to achieve expression in the form of a lyrical poem but rather materializes in a discontinuous sequence of signifiers - "brrr bright" - rendering interpretation or translation decidedly hit-or-miss: a predicament only exacerbated by the poem's sense of the chasm between the lost Irish language and modern Hiberno-English.

brrr bright What? It was the day-time? 
"The Rape of the Aisling" would seem, therefore, to be a cousin to these antiaislingi in that its narrative of sexual violence against the female figure is so grotesquely at odds with the classical aisling's decorous exchange between poet and spéirbhean. So too in its diminution of the sky-woman's status. In the early aislingi she possesses a prophetic knowledge that elevates her above the poet who, in recording and transmitting her vision, is more a scribe than an active protagonist in the encounter. It is she who is the source of the poem's vision and its redemptive message, and as such her epistemological power complicates later readings of her as merely a passive figure of the gendered nation: indeed, once she vanishes it is the poet who is left behind, "exhausted and bewildered." ${ }^{32}$ Having said that, it is not just her words that draw the poet to her: sexuality is almost always at play. The poet's gaze is constantly drawn to her hair, lips, cheeks, and breasts, all of which are described in highly formulaic terms. ${ }^{33}$ In some aislingi, the spéirbhean has been subjected to sexual violence by the invaders, but never in the encounter between poet and sky-woman is any form of violence intimated.

So when, in Montague's poem, the male protagonist moves effortlessly from predation to violation we sense a profound shift in the gender/sexual relationships of the aisling in both its "high" form and its later popular incarnations. Nowhere in the traditional aisling is sexual violence as menacing (particularly in its use of parachesis) as here:

And then my hands wound round her neck

As gently I eased her upon her back[.]

Or as gratuitous as here:

She swore she was true Gael and free

So I placed my hand above her knee, And all the rest of her country -[.] 
Whereas almost all earlier aislingi held out some hope of emancipation (even if it was imagined in terms of obeisance to an aristocratic redeemer and even if it was sometimes dashed as soon as it was uttered) the only freedom offered by this encounter is sexual adventure for the protagonist who, we learn in the final stanza, is indeed a priest. In this baneful encounter the "she" 34 is silent and the poem's vision - its aisling - swings away violently from the idealised rendering of the spéirbhean and her message of hope to a scenario of unmitigated hatred of women as the protagonist takes full advantage of her declaration that she is "free". The echoes of the emancipatory promise of early aislingi are not what concerns the narrator of this ballad: for him "free" indicates sexual availability without cost. It is without cost because, as we shall see, the female figure is without worth, is nothing. Disconcertingly, the protagonist's debasement of the female is sanctioned by the intervention of a figure integral to Catholicism: ${ }^{35}$

My guardian angel in the weeping dawn

Showed that her I held my paragon

Was only the usual parcel of bone[.]

Offering no emancipatory vision and possessing only residual traces of her earlier status as spéirbhean, the female, who because of her subordination and passivity I cannot read as anything other than a child or a very young woman (a sense fortified by "her little snood"), is reduced to a "culchie", a term that for all its being described as "mildly derogatory" by the $O E D$ takes on a decidedly pejorative colouring as the poem progresses. Although in the classic aisling the spéirbhean was encountered in a pastoral setting, she was not bound to that location nor, for that matter, to any earthly place. She was, as Joep Leerssen observes, a "veritable floating signifier who is clearly not a mere mortal, but perhaps a fairy, or a heavenly emissary." 36 And indeed there is something decidedly Marian about the apparition of the classic spéirbhean. But now, as a mere "culchie", she is associated - repeatedly, insistently - with the back-of beyond, with the woods. ${ }^{37}$ And because the aisling's impurity allows the presence of multiple cultural and linguistic codes (including English), she is regarded by the poem's male voice as rubbish, as waste matter.: "only the usual parcel of bone", something you'd throw to 
the dogs. And this is not a judgement restricted to this female figure alone. The blandest of adjectives, "usual", introduces repetition and proliferation into the frame, intimating that numerous girls / young women have passed through the hands of this abuser. In fact, "usual" expands exponentially to include every woman, all women. In a messy amalgam of rhyme and alliteration ("she" = "culchie" = "country") and homophony ("country" = "cuntry") the poem mobilises the old trope of woman as nation to imagine a new phase of violence perpetrated, not by English invaders, but by a home-grown patriarchy, the "access-all-areas men in black" who abused and raped children and young people in their care.

The inevitable echoes here with Hamlet's "country matters" are mirrored in another poem by Montague - a kind of companion piece to "The Rape of the Aisling". "Country Matters" charts the diminishment of female subjectivity - from spéirbhean figure to "backstreets whure" in a manner almost identical to the swift diminution of the female (from "paragon" to "usual parcel of bone") in "The Rape of the Aisling". Furthermore, Amy Cook's superb discussion of the scene in Hamlet (3.2.119-128) has a particular resonance for my present discussion:

Ophelia dodges Hamlet's question about 'country matters' by echoing Claudius's retort to the petulant prince: "I think nothing, my lord" (3.2.116). Again, Hamlet manipulates "nothing" into something, calling Ophelia's nothing "a fair thought to lie between maids' legs". In Hamlet's dexterous use of words, nothing is suddenly the genital space, and Ophelia's nothing must be viewed through the mental space of the penis's thingness. Compared to Hamlet's thing, Ophelia's is absent[.. $]^{39}$

As with Prince Hamlet's debasement of Ophelia to nothing more than a "genital space", so too in "The Rape of the Aisling" the woman's thing - the bodily thing to which the speaker (and his bodily things - his "hand", his "pride and glory") is ultimately drawn is also a "non-thing", a nothing. The epistemological violence embedded in "country' does much to activate the amalgam of lust and disgust, attraction and repulsion at the heart of the poem's sexual scene. And just as Ophelia becomes nothing, the unnamed woman of Montague's poem is diminished in the space of a few lines of doggerel to nothing. 
Punctuating this narrative of misogynistic abuse there is desire uttered time and again in the apostrophic refrain, the "O" of which works doubly to, first of all, suggest a jouissance that remains undiminished even after the protagonist's "long repentance" 40 and, simultaneously, to insist repeatedly on the nothingness of the female figure, on her reduction to the "O" of her genital space. As with the title - to which I will turn in a moment - the refrain works both to consolidate and to destabilise the poem. ${ }^{41}$ Made up as it is of triple trochees, the refrain imposes an order of sorts on the wayward, mainly iambic rhythms and the rough-and-ready rhyme of the first three lines of each verse. In song and in ballads, the refrain provides an opportunity for the audience to join with the individual performer. The singer is no longer a lone voice but is momentarily fortified by a community of listeners who become fellow participants, a process not dissimilar to the congregation's responses in the Catholic mass. By joining the refrain, the audience gives assent to the sentiment of the song, validating it without necessarily knowing (nor having the time to reflect on) the details contained within the verses. Were we to join the refrain of "The Rape of the Aisling" we might at first experience the jocularity of what initially seems a mildly bawdy utterance: "O my culchie darling!" But as things progress I suspect that we would begin to feel at the very least uncomfortable with the way in which the verse narrative comes to contaminate what might otherwise be regarded as a variant of the standard lover's apostrophe found in popular eighteenthand nineteenth-century aisling-type poems such as "The Colleen Rue" or "My Dark Rosaleen". The warring nature of the refrain does nothing to quell the competing strains of desire and hatred, attraction and abjection at work in the poem. Indeed, the word "refrain" here seems to be at war with itself as its competing significations - to repeat and to abstain from - gather together the incompatible strains within the speaker.

And then there is the title. Even before the poem proper begins, we seem to have an (authorial) ${ }^{42}$ insistence that what is to follow will constitute the rape of the aisling. The title is at once emphatic, in that there is no doubt that the reader's responses to the actions set out by the poem's voice or its scriptor are being primed, ${ }^{43}$ and polysemous, in that via the portal of the title various literary antecedents instantly enter the frame. As well as invoking the entire history of Irish vision poetry, there are echoes of Alexander Pope's "The Rape of the Lock" (1712) and, with its attention to items of clothing, perhaps too Giles Jacob's pornographic satire on Pope's poem, “The 
Rape of the Smock" (1717). Famously, Pope's poem was an attempt to ameliorate a quarrel between two prominent English recusant families, a quarrel occasioned by, as Leonard Smithers noted in the introduction to his 1897 edition, "a frolic, carried rather beyond the bounds of good breeding, in which Lord Petre cut off a lock of Mrs Arabella Fermor's hair." 44 Magnified by Pope into the "dire Offence" of the cutting of a lock of Belinda's hair by the Baron, the poem's comic effect relies on the incommensurability of the actual act with its rendering in the rococo narrative. More broadly, Pope's poem is a satire on the morals, manners, and ultimately trivial concerns of bourgeois English society at the time of its composition. Montague's poem too is a satire, but one in which the term "rape" is deployed not for mock-heroic amusement but for a darker purpose. The relationship of title to text is notoriously unstable but there is the sense here that the title performs an extradiegetic comment on the sexual assault related at first so blithely and then so dismissively by the narrative voice of the poem. That the title insists that this is a rape as opposed to how the poem's voice regards it (his attempts at repentance suggests a sense of moral failure) repudiates the Church's long-standing position on child abuse, a position it maintained until it was belatedly forced to confront the criminality and not simply the immorality of some of its clerics.

Alternatively, we may regard the title as symptomatic of a conflict within the protagonist himself, a conflict that Marie Keenan found to be present in almost all the clergy who had abused children in their care. ${ }^{45}$ Such a reading provides, if not exactly an analysis of "the conflict between the call to the priesthood and sexual desire", 46 then at the very least a glimpse into what was for some men and women of the Church an unresolved tension, the results of which were often profoundly frustrating for them and too often catastrophic for those children and young people in their care. Unless we are content to read the protagonist-priest as purely monstrous (and given the number of priests scattered across Montague's oeuvre, almost all of whom are rendered in a sympathetic light, such a reading would probably be erroneous), we can discern in the interplay of title, refrain and narrative an insight into the confusion that can arise in a life of imposed celibacy. This was an imposition that when interwoven with other factors that contributed to young men being ordained for the priesthood (and young women entering religious orders) often produced degrees of disappointment and 
frustration that resulted on far too many occasions in terrible damage to the individuals themselves and to their charges. Diarmaid Ferriter sets out some of these factors:

many who supposedly had vocations for religious work clearly did not, and were the very last people who should have been put in charge of children. Forced celibacy, the young age of entry to religious training and single-sex environments compounded those problems and poisoned the atmosphere these men, women and children lived and operated in. Many of the perpetrators of abuse were victims of ... the internal Church pecking order that deemed certain clerics to be more suited to working in industrial schools. ... They were products of a uniquely Irish mixture of large families, thwarted ambitions, rigorous segregation of the sexes and lack of economic opportunity, as were the children they took out their frustration on, often in the most sadistic of ways. ${ }^{47}$

Following the revelations of decades of sexual abuse of children perpetrated by "some of the most revered members" 48 of Irish society, and the knowledge of that abuse by the church hierarchy, one could be forgiven for assuming that there would now be evidence to corroborate Fintan O'Toole's assertion that "though most Irish people knew ... they did not want to really know." ${ }^{49}$ Similarly, Fin Dwyer's plea that "we must stop claiming that 'we never knew' about child abuse at Catholic institutions" ${ }^{\prime 50}$ implies the existence of a body of proof that might refute protestations of ignorance. That there is precious little to substantiate claims that awareness of abuse extended much beyond the confines of the Church and the victims/survivors and their families does not of course invalidate O'Toole's and Dwyer's views: an unhealthy deference to officers of the Church allied to the "states of fear" induced in those victims and their families who dared to voice a complaint meant that any open discussion of abusive clergy was ruthlessly suppressed. But all the same, the lack of substantive evidence should make us hesitate before accepting the totalization implicit in the phrase "most Irish people knew" or the complicity assumed by Dwyer's doubled use of the first person plural pronoun. The Murphy Report of 2009 revealed the lengths to which the Church authorities in Ireland went to maintain "secrecy, cover-up and inaction." ${ }^{51}$ In this they were helped considerably by the Garda Siochána who referred complaints straight back to the Church itself. We would have to wait decades for first- 
hand testimony from survivors to begin the process of opening the doors onto the extent and duration of clerical abuse of children and young people.

This is a process that is far from complete. The possibility of establishing some semblance of truth and justice for victims of abuse at the hands of church officials seems - even after Pope Francis' visit to Ireland in August 2018 - unlikely. Apart from the fundamental problem of finding and testing evidence of criminality that may have occurred up to half a century ago, there is a major obstacle to establishing a satisfactory outcome: namely, the recalcitrance of the Church authorities to full and open disclosure of what was known of the actions of priests such as Fr Brendan Smyth and Fr Seán Fortune and Fr Tony Walsh and Fr Eugene Greene and Fr Thomas Naughton and Fr Patrick McDonagh, and what was done or not done by their superiors to confront the crimes these priests were perpetrating. The various commissions of inquiry have revealed something of the Church's response to child abuse by its priests, but as exTaoiseach Enda Kenny's response to the publication of the Cloyne Report suggests, the Church continues to regard the abuse of young people as a secondary matter:

For the first time in Ireland, a report into child sexual abuse exposes an attempt by the Holy See to frustrate an inquiry in a sovereign, democratic republic ... as little as three years ago, not three decades ago. And in doing so, the Cloyne Report excavates the dysfunction, disconnection, elitism - the narcissism - that dominate the culture of the Vatican to this day. The rape and torture of children were downplayed or 'managed' to uphold instead, the primacy of the institution, its power, standing and 'reputation'. ${ }^{52}$

I am aware that the claims I have been making for "The Rape of the Aisling" may seem a little over-blown. After all, its circulation and readership appear to have been decidedly limited. Its appearance in June 1967 occasioned no scandal and since then it has languished in the archives of the National Library of Ireland provoking not a word of critical commentary. But, along with The Dark and The Rocky Road to Dublin, "The Rape of the Aisling" speaks to us from, to borrow Seamus Heaney's phrase, the "Land of the Unspoken." ${ }^{53}$ It speaks of clerical insouciance, sexual bravado, a lack of guile, an unconcern for repercussions: and in doing so it brings us close to the conditions that permitted a number of priests to exercise unfettered power against some 
of the most vulnerable members of Irish society. Conversely, it speaks of vulnerability and powerlessness, of silence and worthlessness: and in doing so it reaches into the experience of those that for so long had no voice through which to articulate their pain. That "The Rape of the Aisling" is a fictional and allegorical text - there is no evidence that an actual rape informs its narrative - should warn us against regarding it as documentary material on "clerical sexual abuse", a phrase that would not begin to circulate in Ireland until the late-nineteen nineties. But its very existence as a balladthat form of poetry that revels in satire and invective, that unapologetically political form of poetry and song oriented towards a receptive, even a conniving, audience suggests that knowledge of activity unbefitting the priesthood did, to a degree, circulate within the public realm, and that that activity exemplified the overly-intimate relations between Church and State.

Inevitably, for a poem produced in the afterglow of the fiftieth anniversary of the Rising, one senses that in looking back to the betrayed revolution, it is the Proclamation's promise to cherish "all of the children of the nation equally" that has been most grievously compromised. Luke Gibbons senses something very similar at work within The Rocky Road to Dublin that is, he argues,

a requiem for a revolution, a scathing rejoinder to the official complacency and selfcongratulation that accompanied the Golden Jubilee celebrations of the Easter Rising in 1966. Interestingly ... it is not the hopes and energies of the revolutionaries that are mocked, but the traducing of these ideals through the alliance of church and state in the new independent Ireland. ${ }^{54}$

This sense of disappointment brings us to the satirical thrust of Montague's poem. The aisling - as allegory of a nation that found expression in 1916 - has been deformed by a church that for so long wielded hegemonic and largely unchallenged power over the State and its citizens. We now know that beneath the calm surface of a power that extended into every facet of political and social life in Ireland, terrible things were happening to thousands of children and young people. If The Dark is "the first major work of fiction in Ireland to shine a light on clerical sexual abuse", 55 "The Rape of the Aisling" is the first literary text to assert that not only are priests capable of grooming 
children and young people, but that they are capable of raping them. Although there is no evidence that the poet is responding to a particular instance of abuse, nonetheless no other text of the period presents so candidly the dreadful scenario that we now know was occurring in those places in which priests had access to children but at the time and for decades after remained, to all intents and purposes, unspoken.

\footnotetext{
Notes

${ }^{1}$ Murray, "Priests and People," 258. The phrase in my title - "aisling ghéar" - is Irish for "bitter vision" or, more pertinently for this discussion, "broken vision". Appearing first in Agán Ó Rathaille's despairing poem "Mac An Cheannaî", the phrase is probably now more readily associated with Breandán Ó Buachalla's monumental study of seventeenth- and eighteenthcentury Irish Jacobite poetry, Aisling Ghéar: Na Stíobhartaigh agus an t-aos léinn, 1603-1788 (Baile Átha Cliath: An Clóchomhar, 1996).

2 “The Rape of the Aisling" does not appear in any of John Montague's collections of poetry. The poem is laid out here exactly as it appears on the St Sepulchre's Press broadsheet that can be viewed at the Prints and Drawings Collection, National Library of Ireland - call number SEP/14 (B). Just a few months before his death John Montague granted me permission to reproduce the poem in its entirety ... for which I remain immensely grateful.
} 
${ }^{3}$ O'Toole, "Picking the Lock," 3.

${ }^{4}$ Shovlin, "Secular Prayers," 323.

${ }^{5}$ McGahern, Memoir, 252.

${ }^{6}$ This was not the first time that McQuaid had attempted to destroy the livelihood of a writer. Twenty years earlier, on hearing that Frank O'Connor was seeking an annulment of his first marriage and that he was living with his common-law wife, the actor Evelyn Bowen, McQuaid ensured that both O'Connor and Bowen “were deprived of state employment in Irish radio on the grounds that they were giving public scandal by living together": Garvin, Preventing the Future, 57. "In both cases," Garvin adds, "the obsessively sexual nature of the archbishop's preoccupations was obvious": Ibid., 57.

${ }^{7}$ The banning of The Dark is often cited as one of the factors that lead to the relaxation of the censorship laws from 1967 onwards. Brian Lenihan's amended Censorship of Publications Act "limited the period of prohibition orders to twelve years (although books so released could be banned again), and thereby allowed the immediate sale of over 5,000 previously banned books": Kennedy, Dreams and Responsibilities, 142. For a detailed discussion of the banning episode, see Nolan, “'If it was just th'oul book ...,," 261-79.

${ }^{8}$ O'Faoláin, “Dáil and the Bishops,” 12.

${ }^{9}$ Quoted in Schirmer, “"Richly Ambiguous Position”” 82.

${ }^{10}$ Bourke, "Rocks in the Road," 106. Bourke's sense of priestly invincibility is not simply impressionistic. In his discussion of the figure of the priest in the poetry of Paul Durcan, Andrew J. Auge quotes from an extensive survey of Irish Catholics conducted in 1964 by the Jesuit sociologist Bruce Biever who "found that among his sample of over nine hundred Irish [Catholics], there was unanimous agreement with the statement 'I think priests should be given a great deal of respect both by individuals and society,' with 92 percent agreeing strongly and 8 percent indicating a more tempered agreement. ... Even more striking, two-thirds of Irish Catholics ... endorsed the statement that 'Priests have the right and the obligation to tell me how to run my life; if I follow their advice, I can't go wrong": Auge, Chastened Communion, 171. 
${ }^{11}$ See the timeline "How the Story of Abuse Emerged," Irish Times, 27 November 2009, 10.

${ }^{12}$ O'Toole, "Picking the Lock," 3.

${ }^{13}$ Among the mass of material documented by Nolan in his discussion of the public responses to the episode, only one reference to abuse is made, and this in a letter to The Irish Times by Donald Braider of Dublin who talks of the novel's "gimmick" of "the pederastic priest and father.” See Nolan, “'If it was just th'oul book ...,,” 267.

${ }^{14}$ Bourke, "Rocks in the Road," 109.

${ }^{15}$ Keenan, Child Sexual Abuse, 23.

${ }^{16}$ Ferriter, Occasions of Sin, 326.

${ }^{17}$ James Smith regards the suppressed Carrigan Report of 1931 as inaugurating this process. See Smith, "Politics of Sexual Knowledge,” 208-33.

${ }^{18}$ After early screening in two cinemas, in Cork and Dublin, the film was not shown again in Ireland until a restored version was released in 2004.

${ }^{19}$ McGahern, Memoir, 252.

${ }^{20}$ Pettitt, Screening Ireland, 88.

${ }^{21}$ See Adams, Censorship, 50-54 and Ó Drisceoil, "Irish Books Banned,” 644-49. The only poem to be banned in Ireland was Frank O'Connor's famous The Midnight Court: A Rhythmical Bacchanalia from the Irish of Bryan Merryman, his translation of Cúirt an Mheán Oíche. Merriman's original remained uncensored.

${ }^{22}$ Librarian and bibliographer Mary "Paul" Pollard founded the press in 1964. Housed within the Archbishop of Dublin's Liberty of St. Sepulchre, she published sixty-five items most in broadside format with woodcut illustrations - before ceasing production in 1992. Austin Clarke, Seamus Heaney, Brendan Kennelly, Thomas Kinsella and Eiléan Ní Chuilleanáin were among the poets whose work she featured. In addition, she published a range 
of ephemeral texts, including recipes, children's verse, and satires by lesser-known authors concerning political scandals in both parts of the island, albeit with a strong focus on Dublin's political and social life. Thomas Dillon Redshaw cites the establishment of the press and its production of "numerous satirical, scatological, and parodical broadsides" as bolstering Dublin's satirical literary culture: see Redshaw, "Cuimhneachán 1966”, 37.

${ }^{23}$ The broadside ballad is a highly palimpsestic form. Often advertised as "A New Song," the typical broadside was strictly-speaking no such thing, but rather a new or rearranged form of words superimposed onto an existing melody or air. Part of their popularity was that their newness would have seemed familiar, framed as it was within the comfort of something already known. Most of these "new" songs were therefore rejuvenated old songs: the "old" or "original" song vestigially present in a new iteration sparked by the event or scandal that occasioned its appearance.

${ }^{24}$ Deane, Short History, 23.

${ }^{25}$ Kinsella, Fifteen Dead, xx. Far from incidental, the price of ten pence was part of Kinsella's fidelity to the tradition of balladry: "cheapness and coarseness were part of the effect, as with a ballad sheet": Kinsella and Enniss, "Preface," 1. For a vivid sense of the ubiquity of the poem in the weeks after its publication, see Tubridy, Thomas Kinsella, 14-15.

${ }^{26}$ Zimmermann, Songs of Irish Rebellion, 88.

${ }^{27}$ Ibid., 91.

${ }^{28}$ Boland, "Kind of Scar," 22

${ }^{29}$ Walter, "From Aisling to Chora," 313.

${ }^{30}$ Produced at the time of the Republican hunger strikes in the early 1980s, "Aisling" is one of the most widely discussed poem in the contemporary Irish poetic canon, attracting critical commentary from, among others, Edna Longley, Jacqueline Belanger, Toni O’Brien Johnson, and Shane Alcobia-Murphy. See Muldoon, Quoof, 39.

${ }^{31}$ O'Loughlin, Stalingrad: The Street Directory, 24. 
${ }^{32}$ Leerssen, “Ossianic Liminality”, 13.

${ }^{33}$ This is a feature of the genre that Austin Clarke exploits is his highly-eroticised aislingi: notably, "The Straying Student" (1938), “At Morning From the Coldness of Mount Brandon" (1929), "One Day Before Titan had Lighted the Way" (1963), "Morning had Gone into the Wood" (1968), "Song of the Books" (1963), and “Tiresias" (1971).

${ }^{34}$ Although the female figure remains nameless, the use of "she" echoes with sí / sídh (a homophone of "she"), the Irish for both fairy hill or mound and an inhabitant of such places.

${ }^{35}$ The Feast of the Guardian Angels is observed within the Catholic Church on 2 October. That section of the Catechism of the Catholic Church entitled 'The Angels in the Life of the Church' sets out the particular role of guardian angels: "From its beginning until death, human life is surrounded by their watchful care and intercession". And quoting from St Basil's Adversus Eunomium III, the Catechism states: “'Beside each believer stands an angel as protector and shepherd leading him to life'."

${ }^{36}$ Joep Leerssen, “Ossianic Liminality,” 13.

${ }^{37}$ One possible root of "culchie" is Coillte Mách / Kiltimagh, a village in County Mayo. It may also derive from a shortened form of "agriculture": Dolan, Dictionary, 74. Coillte, "woods" or coillteach, "a wooded place": Ibid., 74.

38 “““Culch | cultch, n.”. gen. Rubbish, refuse. (south of Eng. and U.S.)”. OED.

${ }^{39}$ Cook, "Staging Hamlet," 87.

${ }^{40}$ In both the Old and New Testaments "repentance" derives from linguistic roots meaning "turn away from" [sinful activity]. Doctrinally, it is bound up with the concept and practice of penance and is a necessary step towards the soul's salvation. Incense has the function in Christian services of fortifying the power of prayer and is used in purification rituals. It is associated with some of the most solemn of rites (worship, consecration, benediction, etc.).

41 "Whereas the refrain (ritournelle) is essentially territorial, territorializing, or reterritorializing, music makes it a deterritorialized content for a deterritorializing form of expression": Deleuze and Guattari, Thousand Plateaus, 300. 
42 "[P] $]$ resumably by a real author, the title still is part of a so-called literary fiction; but it does not play a role in the same fashion as what is found inside the same fiction": Derrida, "Title (to be Specified)," 14.

${ }^{43}$ Barthes regards the title as, among other things, "a metalinguistic announcement [that] has an aperitive function": Barthes, "Textual Analysis," 134.

${ }^{44}$ Smithers, "Introduction," $v$.

${ }^{45}$ Keenan, Child Sexual Abuse, 129-79.

${ }^{46}$ McGahern, Memoir, 252.

${ }^{47}$ Ferriter, Occasions of Sin, 333-34.

${ }^{48}$ Bourke, "Rocks in the Road," 109.

${ }^{49}$ Ferriter, Occasions of Sin, 402.

${ }^{50}$ Dwyer, "We Must Stop Claiming”, (9 June 2014).

${ }^{51}$ Murphy, Mangan, and O’Neill, Murphy Report, 26.

${ }^{52}$ Irish Times (20 July 2011), 1.

${ }^{53}$ Heaney, Haw Lantern, 18-19.

${ }^{54}$ Gibbons, "The Rocky Road,” 48.

${ }^{55}$ Shovlin, "Secular Prayers," 323. 


\section{Disclosure statement}

No potential conflict of interest was reported by the author. 


\section{References}

Adams, Michael. Censorship: The Irish Experience. Dublin: Scepter Books, 1968.

Anon. "How the Story of Abuse Emerged."” Irish Times, 27 November 2009.

Anon. “Taoiseach’s Speech on Cloyne Motion.” Irish Times, 20 July 2011.

Auge, Andrew J. A Chastened Communion: Modern Irish Poetry and Catholicism. Syracuse, NY: Syracuse University Press, 2013.

Barthes, Roland. "Textual Analysis: Poe's "Valdemar"." In The Narrative Reader, edited by Martin McQuillan, 130-137. London: Routledge, 2000.

Boland, Eavan. "'A Kind of Scar': The Woman Poet in a National Tradition.” Dublin: Attic Press, 1989 
Bourke, Angela. "Rocks in the Road." The Dublin Review 21 (2006): 102-12.

Bunreacht na hÉireann (Constitution of Ireland, enacted in 1937), Article 44.1.2.

Catechism of the Catholic Church. London: Catholic Truth Society, 2016.

Clarke, Austin. Collected Poems of Austin Clarke. Dublin: Dolmen Press, 1974.

Cook, Amy. "Staging Nothing: Hamlet and Cognitive Science." SubStance 35, no. 2 (2006), 83-99.

Deane, Seamus. A Short History of Irish Literature. London: Hutchinson, 1986.

Deleuze, Gilles and Guattari, Félix. A Thousand Plateaus: Capitalism and Schizophrenia II, translated by Brian Massumi. Minneapolis, MN: University of Minnesota Press, 1987.

Derrida, Jacques. “Title (to be Specified).” SubStance 10, no. 2 (1981): 4-22.

Dolan, Terence Patrick. A Dictionary of Hiberno-English. Dublin: Gill and Macmillan, 2012.

Dwyer, Fin. "We Must Stop Claiming that 'We Never Knew' about Child Abuse at Catholic Institutions.” TheJournal.ie. Last modified 9 June 2014. http://jrnl.ie/649607.

Ferriter, Diarmaid. Occasions of Sin: Sex and Society in Modern Ireland. London: Profile Books, 2009.

Garvin, Tom. Preventing the Future: Why was Ireland so poor for so long? Dublin: Gill \& Macmillan, 2004. 
Gibbons, Luke. “The Rocky Road to Modernity”, History Ireland 14, no. 1 (2006): 4850.

Heaney, Seamus. "From the Land of the Unspoken." In The Haw Lantern. London: Faber, 1987.

Keenan, Marie. Child Sexual Abuse and the Catholic Church: Gender, Power, and Organizational Culture. New York: Oxford University Press, 2012.

Kennedy, Brian P. Dreams and Responsibilities. Dublin: The Arts Council / An Chomhairle Ealaíon, 1990.

Kinsella, Thomas and Enniss, Stephen. "Preface.” In Peppercanister 1972-1997: Twenty-Five Years of Poetry - A Bibliography. Atlanta, GA: Emory University Press, 1997.

Kinsella, Thomas. Fifteen Dead. Dublin: The Peppercanister Press, 1979.

Leerssen, Joep. “Ossianic Liminality: Between Native Tradition and Pre-Romantic Taste." In From Gaelic to Romantic: Ossianic Translations, edited by Howard Gaskill and Fiona Stafford, 1-16. Amsterdam: Rodopi, 1998.

McGahern, John. Memoir. London: Faber, 2005.

Montague, John. “The Rape of the Aisling.” Dublin: St Sepulchre's Press, 1967.

Muldoon, Paul. “Aisling.” In Quoof. London: Faber, 1983.

Murphy, Yvonne, Mangan, Ita and O’Neill, Hugh. Report by the Commission of Investigation into the Catholic Archdiocese of Dublin (The Murphy Report) Dublin: Stationery Office, 2009. 
Murray, John A. "Priests and People in Modern Irish History." Christus Rex 23, no. 4 (1969): 258.

Nolan, Val. "“If it was just th'oul book ...': A History of the McGahern Banning Controversy." Irish Studies Review 19, no. 3 (August 2011): 261-279.

Ó Drisceoil, Donal. "Irish Books Banned Under the Censorship of Publications Acts, 1929-67." In The Irish Book in English, 1891-2000, edited by Clare Hutton and Patrick Walsh, 644-49. Oxford: Oxford University Press, 2011.

O’Faoláin, Seán. “The Dáil and the Bishops.” The Bell 17, no. 3 (June 1951), 5-12.

O'Loughlin, Michael. Stalingrad: The Street Directory. Dublin: Raven Arts Press, 1980.

O’Toole, Fintan. "Picking the Lock of Family Secrets." Irish Times, Weekend Review, 1 April 2006.

Oxford English Dictionary, s.v. "culch | cultch, n.” accessed 21 August 2018, http://www.oed.com/view/Entry/45623?redirectedFrom=culch\#eid.

Pettitt, Lance. Screening Ireland. Manchester: Manchester University Press, 2000.

Schirmer, Gregory. “'A Richly Ambiguous Position’: Re-viewing Poisoned Lands, A Chosen Light, and Tides." In Well Dreams: Essays on John Montague, edited by Thomas Dillon Redshaw, 81-94. Omaha, NE: Creighton University Press, 2004.

Shovlin, Frank. "Secular Prayers: Catholic Imagination, Modern Irish Writing and the Case of John McGahern." In Irish Catholic Identities, edited by Oliver P. Rafferty, 321-332. Manchester: Manchester University Press, 2013.

Smith, James M. "The Politics of Sexual Knowledge: The Origins of Ireland's Containment Culture and the Carrigan Report 1931." Journal of the History of 
Sexuality 13, no. 2 (2004): 208-233.

Smithers, Leonard. "Introduction." In The Rape of the Lock: An Heroi-comical Poem. London: F.J. Du Roveray, 1887.

Tubridy, Derval. Thomas Kinsella: The Peppercanister Poems. Dublin: University College Dublin Press, 2001.

Walter, Katharina. "From Aisling to Chora: Female Allegories of the Nation in Contemporary Irish Women's Poetry.” Irish Studies Review 21, no. 3 (2013): 31325.

Zimmermann, George-Denis. Songs of Irish Rebellion: Political Street Ballads and Rebel Songs. Dublin: Allen Figgis, 1967. 